Г.М. Запорожченко, О.Н. Шелегина*

«Сибирские Академины»: женщины-ученые, вошедшие

в историю Сибирского отделения Российской Академии наук

DOI: $10.31518 / 2618-9100-2019-3-19$

УДК 061.12-051(571)“1957”

Выходные данные для цитирования:

Запорожченко Г.М., Шелегина О.Н. «Сибирские Академины»: женщины-ученые, вошедшие в историю Сибирского отделения Российской Академии наук // Исторический курьер. 2019. № 3 (5). Статья 19. URL: http://istkurier.ru/ data/2019/ISTKURIER-2019-3-19.pdf
G.M. Zaporozhchenko, O.M. Shelegina*

\section{"Siberian Academina": \\ women-scientists, who went down \\ in the history of the Siberian Branch of Russian Academy of Sciences}

DOI: $10.31518 / 2618-9100-2019-3-19$

How to cite:

Zaporozhchenko G.M., Shelegina O.M. "Siberian Academina": women-scientists, who went down in the history of the Siberian Branch of Russian Academy of Sciences // Historical Courier, 2019, \# 3 (5). Article 19. [Available online:] http://istkurier.ru/data/2019/ISTKURIER-2019-3-19.pdf

Abstract: This publication opens a series of articles included in the research block of the innovative project "Siberian Academina" initiated by the authors. The article on the basis of analysis of representative historiographic and primary sources shows the relevance and feasibility of studying the role and contribution of women in the formation and development of the Siberian branch of the Russian Academy of Sciences. The purpose of the article is to study the scientific, pedagogical and social activities of women scientists of the USSR Academy of Sciences - Siberian Branch of the Russian Academy of Sciences. The object of the research are scientific biographies of women, full members of the Russian Academy of Sciences, who worked in the Siberian Branch of the RAS. The subject is the process of professionalization of their scientific activity, reflection of its results in the scientific, educational and social sphere of SB RAS. Scientific novelty of the work is related to mnemosophy (since of public memory) - an actual and promising global trend. The contribution of academicians P.Y. Kochina (Polubarinova) and T.I. Zaslavskaya to the development of innovative research in the field of technical and socio-humanitarian sciences is comprehensively shown. The definition of the term "Academina" with the prospect of its development into a scientific concept is proposed. Further publications on this topic will allow for the detailed development and implementation of the complex project "Siberian Academina".

Keywords: Siberian branch of the Russian Academy of Sciences; women scientists, the scientific heritage; mnemosophy; socio-cultural space; "Siberian Akademina"; P.Y. Kochina (Polubarinova); T.I. Zaslavskaya

The article has been received by the editor on 25.04.2019.

Full text of the article in Russian and references in English are available below.

Аннотация. Данная публикация открывает серию статей, входящих в исследовательский блок новационного проекта «Сибирские Академины», инициированного авторами. В статье на основе анализа репрезентативного историографического и источникового ресурса показана актуальность и целесообразность изучения роли и вклада женщин в становление и развитие Сибирского отделения Российской академии наук. Целью представленной статьи является

\footnotetext{
* Запорожченко Галина Михайловна, доктор исторических наук, ведущий научный сотрудник Института истории Сибирского отделения Российской академии наук (Новосибирск, Россия), e-mail: galinakoop@yandex.ru Zaporozhchenko Galina Mikhailovna, Doctor of Historical Sciences, Leading Researcher, Institute of History of the Siberian Branch of the Russian Academy of Sciences (Novosibirsk, Russia), e-mail: galinakoop@yandex.ru Шелегина Ольга Николаевна, доктор исторических наук, ведущий научный сотрудник Института истории Сибирского отделения Российской академии наук (Новосибирск, Россия), e-mail: oshelegina@yandex.ru

Shelegina Olga Nikolaevna, Doctor of Historical Sciences, Leading Researcher, Institute of History of the Siberian Branch of the Russian Academy of Sciences (Novosibirsk, Russia), e-mail: oshelegina@yandex.ru
} 
изучение научной, педагогической и общественной деятельности женщин-ученых СО АН СССР - СО РАН. Объектом исследования избраны научные биографии женщин действительных членов Российской академии наук, работавших в Сибирском отделении РАН. Предметом - процесс профессионализации их научной деятельности, отражение ее результатов в научно-образовательной и социальной сфере СО РАН. Научная новизна работы связана с проведением ее в рамках актуального перспективного мирового тренда - мнемософии - науки о публичной памяти. Всесторонне показан вклад академиков П.Я. Кочиной (Полубариновой) и Т.И. Заславской в развитие новационных исследований в области технических и социогуманитарных наук. Предложено определение понятие «Академина» с перспективой его развития в научный концепт. Дальнейшие публикации по данной теме позволят осуществить детальную разработку и реализацию комплексного проекта «Сибирские Академины».

Ключевые слова: Сибирское отделение Российской академии наук; женщины-ученые; научное наследие; мнемософия; социокультурное пространство; «Сибирские Академины»; П.Я. Кочина (Полубаринова); Т.И. Заславская.

$$
* * *
$$

«Академина» - понятие, ассоциирующееся с фундаментальной наукой и акцентирующее в нем аспект феминности, - стало названием фестиваля женщин, работающих в науке, образовании, экономике, впервые проведенного в Новосибирском Академгородке в 2012 г. В настоящее время фестиваль-конкурс «Академина» превратился в резонансное социокультурное мероприятие регионального уровня. Союз женщин Новосибирской области (HCO), Новосибирское отделение Федерации женщин с университетским образованием, Министерство региональной политики Новосибирской области, Министерство образования, науки и инновационной политики НСО, Сибирское отделение Российской Академии наук, Совет ректоров вузов НСО интегрируют свои позиции для повышения престижа женщинученых, педагогов, специалистов в сфере экономики ${ }^{1}$.

В России и мире действует ряд общественных организаций женщин-ученых. Широкую известность получила деятельность (с 1995 г.) общественной организации «Лига женщинученых Якутии», созданной с целью содействия научному росту и социальной поддержки женщин-ученых. В настоящее время она объединяет более 700 членов, в том числе 77 докторов и 459 кандидатов наук².

Международный день женщин и девушек в науке был установлен, согласно резолюции Генеральной ассамблея ООН, в 2015 г. 11 февраля Организация объединенных наций призывает все государства мира акцентировать внимание на продвижении идей равного участия женщин во всех областях, связанных с развитием научных знаний³.

Проблемы и перспективы участия женщин в развитии науки и образования в современных условиях приобретают широкое общественное звучание и научную актуальность на всех уровнях от международного до национального и регионального.

Накоплен значительный ресурс отечественных и зарубежных публикаций, отражающих гендерный подход к истории мировой и российской науки, образования. Роль женщин в научных исследованиях в XX - начале XXI в. анализируется, в частности, в работах Г.П. Вдовыкина ${ }^{4}$, Е.А. Осиповой ${ }^{5}, \quad$ А.Б. Остапенко ${ }^{6}$ Н.Л. Пушкаревой ${ }^{7}, \quad$ А. Циммера ${ }^{8}$. Наиболее известные исследования о «женской истории науки» в Сибири - это книги о

\footnotetext{
${ }^{1}$ Достопримечательное место «Новосибирский Академгородок»: научное и историко-культурное наследие / Н.Н. Покровский, Г.М. Запорожченко, О.Н. Шелегина. Новосибирск, 2018. С. 155-157.

${ }^{2}$ URL: https://yandex.ru/search/?text=лига\%20женщин\%20ученых\%20якутии\&lr=65\&clid=2163 (дата обращения: 27.01.2019).

${ }^{3}$ URL: https://ria.ru/20170211/1487678584.html (дата обращения: 24.01.2019).

${ }^{4}$ Вдовыкин Г.П. История и социология науки: женщины в современной науке // Вопросы гуманитарных наук. 2010. № 6. C. 25-25.

${ }^{5}$ Осипова E.A. Анализ гендерных показателей академического сектора науки: (на примере Российской академии наук) // Концепции. 2001. № 1/2. С. 29-35.
} 
В.В. Хвостовой ${ }^{9}$ и П.Я. Полубариновой-Кочиной ${ }^{10}$, женщинах-ученых Якутии ${ }^{11}$ Все они представляют собой сборники статей, воспоминаний и справочных материалов о жизни и деятельности ученых. Тот факт, что сама П.Я. Полубаринова-Кочина являлась автором наиболее значительной работы о С.В. Ковалевской ${ }^{12}$, выявившей и введшей в научный оборот объемный архивный материал, придает дополнительную актуальность теме, тесно интегрированной в контекст истории мировой науки.

Характер имеющихся научных публикаций свидетельствует о популярности исторического направления исследований, в объектно-предметную область которого входят женщины-ученые. Вместе с тем для анализа весьма значительного ресурса научной литературы, опубликованных источников, выявления историографических тенденций целесообразно проведение специального монографического исследования, отражающего роль женщин в становлении и развитии приоритетной формы организации науки в середине XX - начале XXI в. - Сибирского отделения Российской Академии наук. Проект «Сибирские Академины» инициируется авторами статьи как комплексный, включающий историкобиографическую и социокультурную составляющие. Нацеленность на получение отсутствующего до настоящего времени систематизированного исторического знания и востребованность в социокультурных мероприятиях, позиционирующих возрастающую роль женщин в научно-образовательной сфере Сибирского региона, позволяет считать его актуальным и перспективным. Интеграция объективного научного знания и эффективных социокультурных практик, разработанных на его основе, обеспечит новационный подход к исследованию новых аспектов академической науки в Сибири, освоению научного и историко-культурного наследия.

Данная публикация открывает серию статей, входящих в исследовательский блок проекта. Ее целью является изучение научной, педагогической и общественной деятельности женщин-ученых СО АН СССР - СО РАН. Объектом исследования избраны научные биографии женщин действительных членов Российской академии наук, работавших в Сибирском отделении РАН. Предметом - процесс профессионализации их научной деятельности, отражение ее результатов в научно-образовательной и социальной сфере СО РАН. Проект «Сибирские Академины» существенно детализирует представления о реальном процессе развития сибирской науки, акцентируя внимание на уникальности вклада известных сибирских женщин-ученых, формирует ряд индивидуально-биографических образов, которые воспринимаются как образец достойного служения Отечеству, творческой самореализации личности, проявления гражданской позиции в драматических условиях эпохального исторического значения.

Источниками для исследования послужили материалы электронного фотоархива $\mathrm{CO}^{\mathrm{PAH}}{ }^{13}$, историографический и информационный ресурс юбилейных изданий «Российская академия наук. Сибирское отделение: Исторический очерк», «Российская академия наук. Сибирское отделение: Персональный состав» ${ }^{14}$, в подготовке которых принимали участие и авторы статьи, а также «Исторической энциклопедии Сибири» ${ }^{15}$, книг из серии «Наука Сибири в лицах», юбилейных публикаций, интервью, воспоминаний, некрологов.

\footnotetext{
${ }^{6}$ Остапенко А.Б. Женщины в российской науке и образовании // Вестник Хабаровской государственной академии экономики и права. 2011. № 2. С. 90.

${ }^{7}$ Пушкарева Н.Л. Женщины в российской науке конца XX - начала XXI века: обобщение количественных характеристик // Женщина в российском обществе. 2010. № 3. С. 24-35.

${ }^{8}$ Цимлер А. Пришло время женщин! // Знание-сила. 2010. № 2. С. 72-74.

${ }^{9}$ Вера Вениаминовна Хвостова - учитель и друг / отв. ред. В.К. Шумный, И.К. Захаров. Новосибирск, 2010.

${ }^{10}$ Пелагея Яковлевна Полубаринова-Кочина / отв. ред. В.В. Пухначев. Новосибирск, 2013.

${ }^{11}$ Женский лик науки Якутии: сборник очерков и справочных материалов о женщинах-ученых Якутии. Якутск, 2015.

${ }^{12}$ Полубаринова-Кочина П.Я. Софья Васильевна Ковалевская, 1850-1891. М., 1981.

${ }^{13}$ URL: http://www.soran1957.ru/ (дата обращения: 29.01.2019).

${ }^{14}$ Российская академия наук. Сибирское отделение: Персональный состав / Е.Г. Водичев, Г.М. Запорожченко, О.Н. Калинина и др. Новосибирск, 2007.

${ }^{15}$ Историческая энциклопедия Сибири): в 3 т. Новосибирск, 2009.
} 
Методологическую основу исследования составляют основные принципы современной исторической науки: историзм и научная объективность, источниковедческий анализ и синтез, в том числе в рамках «новой биографической истории» («социальной персональной истории») и просопографии, изучающих социальную и культурную ситуацию, по отношению к которой описываемая биография приобретает значение истории. Это позволило, с одной стороны, исследовать уникальные особенности индивидуальных научных биографий женщин-ученых, а с другой - выявить общие черты, характерные для процесса интеграции женщин в сферу профессиональной научной деятельности, через создание «коллективных научных биографий».

Серия исследований «Сибирские Академины» будет базироваться на использовании и развитии социокультурного подхода, позволяющего проводить комплексный анализ общества как единства культуры и социальности, образуемых и преобразуемых деятельностью человека. Личность в рамках данного подхода рассматривается в неразрывном единстве с обществом и культурой.

Авторами впервые в данном исследовательском поле будут внедряться и апробироваться положения актуального и перспективного мирового тренда - мнемософии - науки о публичной памяти, новой ценностной области социогуманитарных наук, которая поможет сделать наш мир лучше ${ }^{16}$. Солидаризируясь с Т. Шолой, мы считаем, что «публичная память служит как отдельным людям, так и всему обществу, поэтому забота о ней является естественной обязанностью всех членов общества» ${ }^{17}$.

В данной статье мы отдаем дань глубокого уважения женщинам-ученым, закончившим свой славный жизненный путь, чьи имена вошли в историю СО РАН. В центре внимания данного очерка первые действительные члены РАН в Сибирском отделении академики Пелагея Яковлевна Кочина (Полубаринова) (1899-1999 гг.) и Татьяна Ивановна Заславская (1927-2013 гг.).

В фундаментальном труде «Российская академия наук. Сибирское отделение: Исторический очерк» ${ }^{18}$ отмечены также женщины-ученые, внесшие важный вклад в деятельность СО РАН. Вера Вениаминовна Хвостова (1903-1977 гг.), доктор биологических наук, профессор, в числе известных генетиков была приглашена в штат на начальном этапе формирования Института цитологии и генетики СО РАН ${ }^{19}$.

Инесса Тихоновна Журавлева (1921-2007 гг.) - выдающийся ученый в области наук о Земле, внесшая крупный вклад в разработку проблем палеонтологии, стратиграфии, палеобиогеографии и палеоэкологии кембрийского периода в истории Земли - начального этапа в формировании биосферы современного типа (около 500 млн лет назад). И.Т. Журавлева - доктор геолого-минералогических наук, являлась одной из первых в Сибирском отделении, защитивших докторскую диссертацию. Как известно, первые докторские защиты состоялись в Новосибирске в 1960 г., когда диссертации защитили «математик П.П. Белинский, геолог И.Т. Журавлева, химик С.С. Бацанов» ${ }^{20}$. «В 1960 г. произошло знаковое событие в истории Новосибирского научного центра, писали в некрологе, посвященном И.Т. Журавлевой, Н.Л. Добрецов и другие ее коллеги, состоялась защита первой докторской диссертации, положившей начало одной из главных в стране “кузниц" научных кадров высшей квалификации. Автором этой диссертации была И. Т. Журавлева. В этом выдающемся исследовании были обобщены с исчерпывающей полнотой практически все накопившиеся к тому времени данные по морфологии, систематике, стратиграфическому и геологическому распространению археоциат

\footnotetext{
${ }^{16}$ Шола Томислав С. Мнемософия. Эссе о науке публичной памяти. Ростов Великий, 2017. С. 171.

${ }^{17}$ Там же. С. 77.

${ }^{18}$ Российский академия наук. Сибирское отделение: Исторический очерк / Е.Г. Водичев, С.А. Красильников, В.А. Ламин и др. Новосибирск, 2007.

${ }^{19}$ Там же. С. 143.

${ }^{20}$ Российский академия наук... Исторический очерк. С. 212.
} 
в кембрийских отложениях Сибири и Средней Азии. С этого времени труды И. Т. Журавлевой по археоциатам получили мировое признание» ${ }^{21}$.

Нина Ивановна Гринева (1927-2018 гг.) - ученый в области молекулярной биологии и биоорганической химии, доктор химических наук, профессор, специалист в области лечения онкологических заболеваний системы кровообращения. Н.И. Гринева работала в Новосибирском Академгородке в 1962-1975 гг. под руководством профессора Д.Г. Кнорре. В 1990 г. Удостоена звания лауреата Ленинской премии совместно с Д.Г. Кнорре, Р.И. Салгаником, 3.А. Шабаровой ${ }^{22}$.

Елизавета Ивановна Убрятова (1907-1990 гг.) - видный лингвист-тюрколог, специалист в области грамматики и диалектологии якутского языка и тюркских языков, доктор филологических наук (1953 г.), профессор, заслуженный деятель науки Якутской АССР (1956 г.) и Тувинской АССР (1977 г.). Е.И. Убрятова стояла у истоков филологической школы СО АН, ее труды определили развитие исследований по данным проблемам на многие десятилетия вперед ${ }^{23}$.

Первой сибирской «Академиной» можно по праву считать Пелагею Яковлевну Кочину (Полубаринову). Она родилась 1(13) мая 1899 г. в с. Верхний хутор Астраханской губернии в крестьянской семье. В 1916 г. окончила с золотой медалью Покровскую женскую гимназию в Петрограде и поступила на Высшие женские Бестужевские курсы, которые в 1919 г. были объединены с Петроградским государственным университетом. Ее двойная фамилия сложилась в 1925 г. в результате брака с Н.Е. Кочиным (1901-1944) - выдающимся отечественным математиком и механиком, действительным членом АН СССР (1939 $)^{24}$ (Рис. 1).

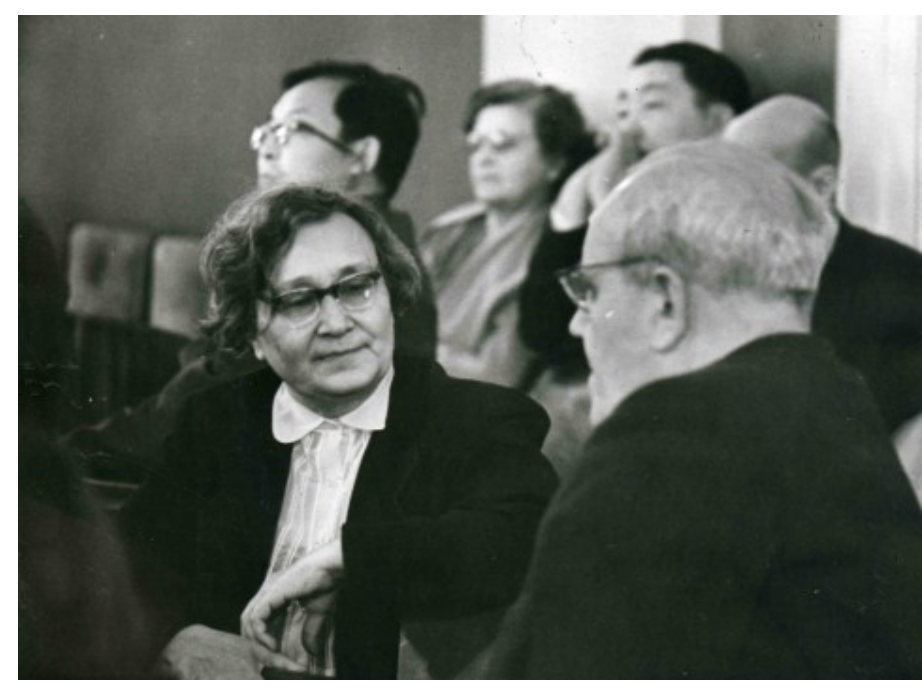

Рисунок 1. П.Я. Кочина и Г.А. Пруденский на Первом Общем собрании СО АН СССР. Май 1958 г., Новосибирск (Архив Р.И. Ахмерова // Электронный фотоархив СО РАН «Фотолетопись СО РАН с 1957 года».

URL: http://www.soran1957.ru/?id=PA_folders0120_0001_0706 (дата обращения: 27.01.2019).

Имя П.Я. Кочиной (Полубариновой) названо в составе созвездия выдающихся ученых в области механики и энергетики, сформировавших и возглавивших научные коллективы в период становления и развития Сибирского отделения АН СССР. Член-корреспондент АН СССР П.Я. Кочина возглавила в Институте гидродинамики (директор - академик М.А. Лаврентьев) актуальное направление по изучению проблем гидростроительства и

\footnotetext{
${ }^{21}$ Наука в Сибири. 2007. № 30-31 (2615-2616). 9 авг.

${ }^{22}$ Российская академия наук... Исторический очерк. С. 253; Высокоточное оружие против вирусов / Интервью с В.В. Власовым // Наука в Сибири. 1998. № 45-46 (2181-2182).

${ }^{23}$ Российская академия наук... Исторический очерк. С. 254.

${ }^{24}$ Институт гидродинамики: люди, дела, даты... / отв. ред. А.А. Васильев. Новосибирск, 2017.
} 
грунтовых работ ${ }^{25}$. До приезда в Новосибирск П.Я. Кочина имела успешный опыт преподавательской и научно-исследовательской деятельности. Окончила в 1921 г. физикоматематическое отделение Петроградского университета, работала в Главной геофизической обсерватории (1919-1927), преподавала в Ленинградском институте инженеров гражданского воздушного флота (1924-1935). В 1934 г. она получила ученое звание профессора, преподавала в столичных вузах, в т. ч. в Московском государственном университете (1947-1949). С 1935 г. вела исследовательскую деятельность в Математическом институте им. В.А. Стеклова АН СССР, затем работала в Институте механики АН СССР, стала доктором физико-математических наук (1940). В 1946 г. П.Я. Кочина избирается членом-корреспондентом АН СССР как признанный российский математик, механик, специалист в области гидродинамики. За книгу «Некоторые задачи плоского движения грунтовых вод» она получила Сталинскую премию II степени. С 1948 г. до перехода на работу в Сибирское отделение она возглавляла отдел в Институте механики AH CCСР, являлась членом Национального комитета по теоретической и прикладной механике (с 1956), экспертной комиссии АН СССР по премии им. С.А. Чаплыгина (с 1958). Общественно-политическую деятельность Пелагея Яковлевна вела в статусе депутата Верховного Совета РСФСР (1951-1959), получила заслуженные награды - ордена Трудового Красного Знамени (1945), Ленина (1953) ${ }^{26}$.

На первых выборах на вакансии СО АН СССР, состоявшихся 27-28 марта 1958 г., было избрано восемь действительных членов и 27 членов-корреспондентов. Академиками стали И.Н. Векуа, П.Я. Кочина, В.Д. Кузнецов, А.И. Мальцев, Ю.Н. Работнов, В.С. Соболев, А.А. Трофимук, А.Л. Яншин. Председатель СО АН СССР академик М.А. Лаврентьев, давая характеристику П.Я. Кочиной отметил: «Академик П.Я. Кочина, известная своими трудами по гидромеханике и теории фильтрации, в Институте гидродинамики возглавила отдел прикладной гидродинамики. Под ее руководством и по ее инициативе здесь начали проводиться расчеты на ЭВМ при решении задач движения грунтовых вод и речных потоков. Она одной из первых окончательно переехала в строящийся Академгородок...» ${ }^{27}$.

Свои впечатления от встречи с первой в Сибири женщиной-академиком передают московские журналисты Б. Евладов и С. Мокшин, посетившие Новосибирский Академгородок. Приведем фрагмент очерка «Живая вода». «Ни возраст, ни суровые условия не остановили Пелагею Ивановну в ее стремлении помочь освоить природные богатства восточных областей страны. В 1959 году, когда еще в помине не было замечательных коттеджей Золотой долины, Кочина уже развернула первые исследования. В ее щитовом домике разместились и лаборатория, и общежитие молодых сотрудниц института. Гарнитур полированной мебели причудливым образом дополнили ящики из-под химических реактивов. На них были установлены приборы. Но главная работа выполнялась под открытым небом. Каждое лето во главе экспедиции П.Я. Кочина отправлялась в Кулундинские степи, чтобы оказать помощь хозяйствам, заложить новые эксперименты, на практике проверить теоретические выводы» ${ }^{28}$.

П.Я. Кочина играла в Сибирском отделении весьма значимую научно-организационную роль: член Президиума СО АН СССР (1961-1963), председатель Комиссии АН СССР по использованию и охране водных ресурсов Сибири (1959-1970), председатель Межведомственной координационной комиссии СО АН СССР по орошению и обводнению Кулундинской степи (1959-1960). Комиссия СО АН по исследованию и охране водных ресурсов Сибири под председательством П.Я. Кочиной (1962-1969) проводила экологоэкономическую экспертизу ряда масштабных проектов мелиоративного и водохозяйственного строительства. Совместно с Л.В. Канторовичем в рамках создания

\footnotetext{
${ }^{25}$ Российская академия наук... Исторический очерк. С. 140, 238.

${ }^{26}$ Российская академия наук... Персональный состав. С. 126-127.

${ }^{27}$ Российская академия наук... Исторический очерк. С. 151-152.

${ }^{28}$ Евладов Б.В., Мокшин С.И. Золотая долина. Академгородок. (Репортаж из Новосибирского научного центра). M., 1966. C. 42.
} 
рациональной системы орошения организовала разработку моделей оптимизации структуры сельскохозяйственного производства на орошаемых массивах с пользованием методов математико-экономического анализа.

В период работы в Сибирском отделении, будучи заведующей отделом прикладной гидродинамики Института гидродинамики СО АН СССР, преподавала в Новосибирском государственном университете, заведовала кафедрой теоретической механики. Это отражает роль профессора П.Я. Кочиной в развитии университетского образования. На основе полученных академиком результатов в теории фильтрации грунтовых вод, эффективного математического метода решения задач фильтрации с использованием аналитической теории дифференциальных уравнений П.Я. Кочина сформировала сибирскую фильтрационную школу.

Вклад академика П.Я. Кочиной в развитие фундаментальной академической науки в Сибири, подготовку научных кадров, научно-практическое эколого-экономическое освоение территории Сибирского региона нашел общественное признание, получил самую высокую правительственную оценку - три ордена Ленина (1960, 1967, 1969 г.), звание Героя Социалистического Труда (1969 г.).

В воспоминаниях к 90-летию со дня рождения М.А. Лаврентьева П.Я. Кочина пишет: «Много хороших важных дел сделал Михаил Алексеевич Лаврентьев. И я благодарна ему за Сибирь, за то, что он подарил мне такие интересные годы. И по-доброму проводил в Москву в 1970 году, когда я в пожилом возрасте захотела вернуться к своей семье» ${ }^{29}$.

С 1970 г. П.Я. Кочина продолжила деятельность в Институте проблем механики АН СССР (г. Москва) в качестве заведующей отделом, а затем советника при дирекции (с 1987). В этот период она была избрана членом Научного совета АН по механике жидкостей и газов (1973), удостоена ряда наград орденов: Октябрьской Революции (1975), Дружбы народов (1979), Дружбы (1994), «За заслуги перед Отечеством» III степени (1999), а также золотой медали им. М.В. Келдыша РАН (1996).

Следует особо подчеркнуть широкую известность П.Я. Кочиной как историка математической науки, ставшую автором биографии С.В. Ковалевской, что можно расценивать как поддержку, пропаганду и популяризации роли российских женщин в мировой науке. Отдельные ее книги были посвящены математикам К. Вейерштрассу, Н.Е. Кочину, Г. Миттаг-Лёффлеру, А.А. Фридману. Мемуары П.Я. Кочиной, иллюстрированные рисунками автора, стали ценным источником по истории отечественной науки. В знак признания заслуг Н.Е. и П.Я. Кочиных их имена присвоены малой планете.

П.Я. Кочинова (Полубаринова) прожила долгую жизнь (скончалась 3 июля 1999 г. на 101 году), насыщенную научными успехами, общественными и личными событиями.

Формами публичной памяти о выдающемся российском ученом - академике П.Я. Кочиной - сибирской «Академине» в СО РАН являются премия им. П.Я. Кочиной для молодых ученых, а также посвященная ей книга, вышедшая в серии «История науки в лицах ${ }^{30}$. Показательно, что премию им. П.Я. Кочиной получили за новационные разработки молодые Академины» - продолжатели ее дела: в 2005 г. Ирина Владимировна Жерелина (Институт водных и экологических проблем СО РАН) за цикл работ «Разработка интегрированного подхода к управлению водопользованием на водосборах трансграничных рек Сибири»; в 2008 г. Олеся Евгеньевна Лепокурова (Томский филиал института геологии нефти и газа СО РАН) за цикл работ «Геохимия подземных вод севера Саяно-Алтайского горного обрамления, формирующих травертины»; в 2011 г. Варвара Геннадьевна Ведухина (Институт водных и экологических проблем СО РАН) за цикл «Создание серии геоинформационных карт водных объектов Обь-Иртышского бассейна в целях решения водно-экологических проблем» ${ }^{31}$.

\footnotetext{
${ }^{29}$ Кочина П.Я. Я благодарна ему за Сибирь ... // Век Лаврентьева. Новосибирск, 2000. С. 215.

${ }^{30}$ Пелагея Яковлевна Полубаринова-Кочина...

${ }^{31}$ Женщины в сибирской науке. URL: http://www.prometeus.nsc.ru/archives/exhibit2/womsci2.ssi\#m3 (дата обращения: 25.02.2019).
} 
Как отмечается редакторами книги, посвященной П.Я. Кочиной, в истории науки она «явление поистине уникальное». Родившаяся в конце XIX столетия и прожившая богатый событиями XX век, П.Я. Кочина более 40 лет носила звание академика. На протяжении полувека была «общепризнанным лидером отечественной подземной гидродинамики». Ее научное наследие составляет более 300 статей и книг. Ее учениками созданы научные школы в различных городах и республиках бывшего Советского Союза. В сферу ее чрезвычайно разнообразных жизненных интересов вошли живопись, поэзия, театр, поездки по родной стране и знакомство с другими странами ${ }^{32}$.

Имя члена-корреспондента РАН (1968 г.), впоследствии академика (1981 г.) Татьяны Ивановны Заславской в «Исторических очерках» Сибирского отделения выделяется в связи с международным признанием сложившейся под ее руководством экономикосоциологической школы. «С начала 60 -х годов $\mathrm{XX}$ века в рамках этой школы создана и развивалась оригинальная методология исследования российского общества на разных этапах его развития: системный подход к исследованию деревни, методология изучения социально-территориальной структуры общества, концепция социального механизма развития экономики. На основе накопленных многолетних наблюдений, полученных в экспедициях, были проведены исследования социологии села, миграции сельского населения в город, демографических процессов в Сибири» ${ }^{33}$.

Татьяна Ивановна Заславская (урожденная Карпова) родилась 9 апреля ${ }^{34} 1927$ г. в Киеве. Отец, И. В. Карпов происходил из крестьян ${ }^{35}$, впоследствии стал профессором МПИИЯ (бывшего Московского государственного педагогического института иностранных языков им. Мориса Тореза). Мать, Т.Г. Карпова - из семьи профессора физики Киевского университета Г.Г. Де-Меца, сына бельгийского подданного и русской дворянки, потомственного дворянина с 1913 г.; погибла 21 июля 1941 года во время первой бомбежки Москвы. Бабушка Тани, урожденная Сарра Крафт, имела немецкие корни. Т.И. Заславская сестра выдающегося лингвиста, профессора Новосибирского государственного университета М.И. Черемисиной. Родители-атеисты не разрешили бабушке покрестить сестер, о чем те сожалели и в июле 1988 г. крестились в православном Пюхтицком монастыре в Эстонии ${ }^{36}$.

Таблицу умножения Татьяна Заславская освоила в четыре года, а в пять лет свободно производила арифметические действия с многозначными числами. Ее детство до пятилетнего возраста проходило в Киеве, затем семья переехала в Москву. Начало войны Татьяна встретила в гостях у родителей матери в Киеве, затем уехала в эвакуацию в Ташкент вместе с семьей тети, которая была замужем за известным генетиком M.М. Воскобойниковым. По разным причинам семья Воскобойниковых и Таня не попали в какую-либо ячейку тогдашней социальной сети, предусматривающей организованное снабжение или организованное предоставление жилплощади. От оставшегося в Москве отца, раздавленного безвременной смертью жены, практической помощи было очень мало. Таня и Майя выживали как могли: голод, нищета, болезни, работа в буквальном смысле за кусок хлеба. Не было одежды и обуви, едой считалось несколько изюмин и орехов. Танина тетя М. Воскобойникова писала Таниному отцу, что девочке не имеет смысла устраиваться в 9-й класс школы, чтобы беречь силы, тем более, что весной школьников непременно ушлют «на хлопок». Но жажда жизни и знаний брала свое. Таня пробиралась на лекции своей сестры Майи на филфаке Среднеазиатского Госуниверситета, которые читали Эфрос, Виппер, Колпинский, Федоров-Давыдов.

Летом 1942 г. сестры вернулись в Москву, где Татьяна проявила недюжинную силу духа и в условиях холода и голода еще затемненной военной Москвы экстерном окончила среднюю

\footnotetext{
${ }^{32}$ Пелагея Яковлевна Полубаринова-Кочина... С. 7.

${ }^{33}$ Российская академия наук. Сибирское отделение: Исторический очерк. С. 257.

${ }^{34}$ Во многих изданиях стоит неверная дата ее рождения - 9 сентября.

35 Заславская Т.И. «Я с детства знала, что самое интересное и достойное занятие - это наука» / Интервью // Социологический журнал. 2007. № 3. С. 137-138.

${ }^{36}$ Татьяна Заславская, академик // Воспоминания Ревекки Фрумкиной. URL: http://polit.ru/article/2008/02/22/ zaslav/ (дата обращения: 28.01.2019).
} 
школу. В 1943 г. в возрасте 16 лет поступив в МГУ, она через три года перевелась с физфака на экономический факультет, руководствуясь ставшим «приоритетным интересом к человеческой жизни и управляющим ею законам». Она говорила, что была «ошарашена и ослеплена "Капиталом", величием и последовательностью Марксовой мысли»". Присущая ей сила духа позволила в сжатые сроки совершить крутой поворот в специальности и за один год успешно освоить двухгодичный курс экономики.

Знала ли тогда студентка Карпова, что ей придется вступить в область политэкономии, которая как предмет, в идеологической обстановке СССР, являла собой поистине минное поле. Время написания диплома пришлось на осень 1949 - весну 1950 г. - разгар кампании против космополитов, когда в МГУ исчезли несколько способных студентов. Несмотря на отличное окончание университета, Т. Карпову, выступившую против пятерки, поставленной одному комсомольскому активисту, вообще не посещавшему занятий, решили вместо аспирантуры отправить экономистом на какой-нибудь завод. Ее отстояли блестящие преподаватели А.В. Санина и ее муж В.Г. Венжер, которых Т.И. Заславская с полным основанием будет называть своими вторыми родителями. В результате разнообразных мытарств удалось устроиться в сектор аграрных проблем Института экономики АН СССР ${ }^{38}$.

В Институте экономики Т. Карпова работала младшим научным сотрудником (1950-1953, 1956-1959), старшим научным сотрудником (1959-1963). В 1953-1956 гг. училась в аспирантуре.

Осенью 1952 г. Т. Карпова вышла замуж за Михаила Заславского и сменила фамилию. В условиях антисемитской кампании М. Заславский, будучи профессионалом, с трудом устроился на работу по специальности в области ракетостроения. Вскоре одна за другой появились дочки Аленка и Оксана. Несмотря на семейные обстоятельства, Т.И. Заславская много ездила в экспедиции по колхозам различных областей СССР для сбора материала и в 1956 г. защитила кандидатскую диссертацию «Трудодень и принцип материальной заинтересованности в колхозах» под научным руководством крупного советского экономиста-аграрника В.Г. Венжера.

Полная лишений и упорного труда жизнь не исказили ее характер, доминантами которого оставалась вдумчивость, доброжелательность и готовность в своих изысканиях идти до конца, чего бы это ни стоило. Полностью посвятив себя экономической науке в обстановке несвободы и особой подозрительности, царившей в идеологическом исследовательском институте, молодому ученому предстояло сочетать обязательство умозаключать по приказу партии и классиков марксизма и внутреннюю необходимость думать самостоятельно, как прирожденный исследователь. Рассказы переживших оккупацию родственников и соседей из «раскулаченных» побуждали задуматься о том, что народ живет не так, как ей казалось. В дневнике появилась многозначительная запись: «Нет, я не буду больше так гадко и конфетно болтать о “возрождении” страны. Мне даже стыдно сейчас. И дело вовсе не в том, что она не возрождается, что я лгала, а в том ужас, что Я НЕ ЗНАЮ ${ }^{39}$.

В 1959-1961 гг. молодые кандидаты наук Татьяна Заславская и Маргарита Сидорова занялись проектом разработки методики сопоставления производительности труда в сельском хозяйстве СССР и США, показав, что в конце 1950-х производительность сельскохозяйственного труда в США была выше, чем в СССР, в среднем в 4-5 раз (от 2 раз по зерну до 8-10 раз по мясу и молоку). Но незадолго до окончания работы Н.С. Хрущев с трибуны партийного съезда заявил, что разница составляет «в среднем в 3 раза», поэтому доклад экономистов был забракован отделом науки ЦК КПСС ${ }^{40}$ Жесткий партийный контроль, тотальная секретность, недоступность информации из иностранных источников,

\footnotetext{
${ }^{37}$ Алексеев А.Н. Год Оруэлла в жизни Татьяны Ивановны Заславской. URL: http://www.cogita.ru/a.n.alekseev/publikacii-a.n.alekseeva/god-oruella-v-zhizni-tatyany-ivanovny-zaslavskoi (дата обращения: 25.02.2109).

${ }^{38}$ Татьяна Заславская, академик...

39 Заславская Т.И. Моя жизнь: воспоминания и размышления // Избранное: в 3 т. М., 2007. Т. 3. С. $284-285$.

${ }^{40}$ Мемория. Татьяна Заславская. URL: http://polit.ru/news/2015/04/09/zaslavskaya/ (дата обращения: 28.01.2019).
} 
запрет на публикации по принципу «а вдруг что-то просочится на Запад?» являлись характерными чертами работы в «идеологической» сфере. В тот период для себя самой, без публикации, она пристально изучала причины кризисного развития советского общества. Попытки найти ответы на волновавшие ее как ученого вопросы побудили ответить согласием на настойчивое приглашение Абела Аганбегяна поработать в его лаборатории экономико-математических исследований в Новосибирском научном центре. Командировка затянулась почти на четверть века ${ }^{41}$.

В своих мемуарах «Моя жизнь: воспоминания и размышления» Татьяна Ивановна, как истинный исследователь, нацелившись «на поиск общей логики жизни, которая не лежит на поверхности», выделила 12-летние периоды своей жизни, каждый из которых «имел не только свое возрастное лицо, но, если можно так выразиться, особую функцию или свой сокровенный смысл» ${ }^{42}$. Четвертое и пятое 12-летия жизни Заславской прошли в Новосибирском Академгородке (1966-1988 гг.) (Рис. 2).

Сибирский этап творческой биографии Т.И. Заславской вобрал в себя выдающиеся прорывы в научных исследованиях и академической карьере. Переезд в 1963 г. из Москвы в Сибирь предопределил и переход из экономики в социологию. Работая в Институтке экономики и организации промышленного производства Сибирского отделения СО АН-CO РАН в Новосибирске, Татьяна Ивановна в 1965 г. защитила докторскую диссертацию «Экономические проблемы распределения по труду в колхозах», в 1967 г. стала руководителем отдела социальных проблем. Под ее руководством отдел со временем стал одним из ведущих социологических коллективов страны и получил широкую известность среди ученых за рубежом. В 1968 г. она избрана членомкорреспондентом АН ССCР. Научную работу Т.И. Заславская совмещала с преподавательской деятельностью в Новосибирском государственном университете: с 1972 г. в качестве и. о. профессора, в 1976-1988 гг. - профессора, в 1981-1984 гг. - зав. кафедрой политической экономии.

\section{В 1981 г. Т.И. Заславская была избрана в}

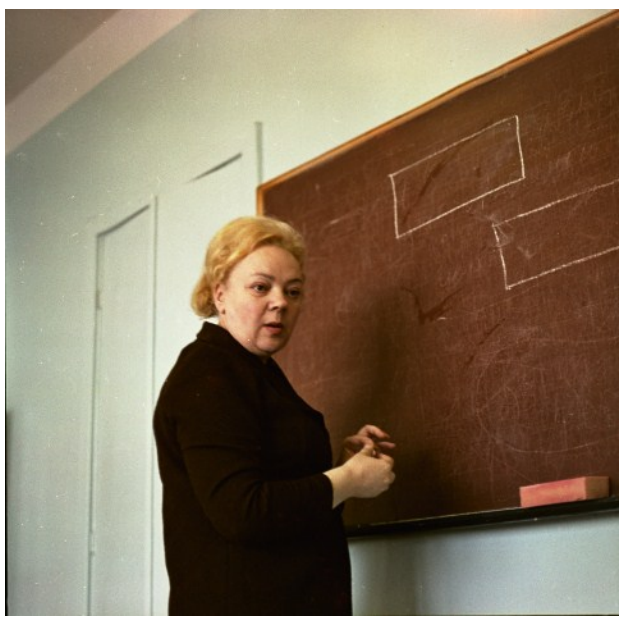

Рисунок 2. Т.И. Заславская. 1975 г., Новосибирск (Архив Р.И. Ахмерова // Электронный фотоархив СО РАН «Фотолетопись CO PAH с 1957 года». URL: http://www.soran1957.ru/? $i d=P A$ folders24-59_0003_0896 (дama обрашения: $\overline{2} 7.01 . \overline{2} 019)$ действительные члены Академии наук СССР, где кроме нее было всего пять женщин. В 1988 г. она была избрана академиком ВАСХНИЛ ${ }^{43}$.

Под ее руководством в тот период были проведены первые в СССР крупномасштабные исследования социально-территориальной структуры села с использованием математикостатистических методов типологического анализа ${ }^{44}$.

Отдел социальных проблем Института экономики и организации промышленного производства СО АН СССР совместно с социологической специализацией экономического факультета НГУ со временем стали ядром созданной Т.И. Заславской Новосибирской экономико-социологической школы (НЭСШ), ключевыми чертами которой были четкие принципы научной работы: междисциплинарность (работа на стыке социологии и экономики); нацеленность исследований на наиболее острые и актуальные проблемы общественного развития; стремление к комплексному, системному изучению социальных

\footnotetext{
41 Заславская Т.И. «Я с детства знала, что самое интересное и достойное занятие - это наука» / Интервью: Социологический журнал. 2007. № 3. URL: http://cdclv.unlv.edu/archives/Interviews/zaslavskaya_07.html (дата обращения: 29.02.2019).

42 Заславская Т.И. Моя жизнь... С. 755-756.

43 Заславская Татьяна Ивановна // Историческая энциклопедия Сибири. Новосибирск, 2009. Т. I. С. 587.

44 Заславская Татьяна Ивановна // Российская академия наук... Персональный состав. С. 98-99.
} 
объектов; сочетание социологических, статистических и математических методов исследования; погруженность в социально-экономическую практику страны и ее регионов; непосредственное знакомство с эмпирическим объектом исследований в ходе социологических экспедиций/обследований ${ }^{45}$.

Возглавляемая Т.И. Заславской Новосибирская экономико-социологическая школа (НЭСШ) признана одним из влиятельных течений в российской общественной науке второй половины $\mathrm{XX}$ в., оказавшим существенное воздействие на институционализацию экономической социологии как самостоятельной научной дисциплины. В 1982 г. академиком Т.И. Заславской и доктором экономических наук Р.В. Рывкиной был впервые прочитан учебный курс «Экономическая социология» в НГУ. Уже к началу нового века школа объединила несколько поколений ученых, проживающих в Новосибирске, Москве, Барнауле и др.

В 1983 г. на представительной конференции в Новосибирске Т.И. Заславская сделала блестящий и значимый для всей отечественной экономической науки доклад о состоянии советской экономики. В нем была показана бесперспективность существования этого хозяйственного механизма и сделан вывод о необходимости кардинальной перестройки социально-экономических отношений ${ }^{46}$. Текст этого доклада стал известен на Западе как «Новосибирский манифест», в котором мир увидел знак грядущих перемен в СССР. В докладе Т.И. Заславская выступила с позиций честного ученого. Несмотря на критическое отношение к социальным институтам советского общества, она была абсолютно лояльна к социалистическому строю, считала необходимым и возможным его совершенствование и вовсе не думала о его сломе или подрыве ${ }^{47}$.

В конце 1980-х гг. в условиях деидеологизации и перестройки социально-экономических отношений руководство СССР начало осознавать потребность в информации об отношении населения к происходившим в обществе кардинальным изменениям. Т.И. Заславской, в сотрудничестве с Б.А. Грушиным и Ю.А. Левадой, доверили организацию ВЦИОМ Всесоюзного центра изучения общественного мнения, создание которого в 1987 г. явилось одним из важнейших научных и политических событий того периода ${ }^{48}$. Таким образом, с возвращением в 1988 г. из Новосибирска в Москву Т.И. Заславская решала крупные задачи как академического, так и организационного свойства. Она - директор Всесоюзного (с 1992 г. Всероссийского) центра изучения общественного мнения (ВЦИОМ) по социальноэкономическим вопросам (1988-1992), президент ВЦИОМ (1993-2003); президент, председатель правления Аналитического центра «Левада-центр» - наиболее авторитетного социологического центра в России (с 2004), сопрезидент Междисциплинарного академического центра социальных наук (Интерцентр) (с 1993); профессор (с 1995), зав. кафедрой методологии общественных наук Московской высшей школы социальных и экономических наук.

Многие годы (1993-2003) она выполняла функцию Президента международного симпозиума «Куда идет Россия?...», который был по тем временам самой авторитетной дискуссионной площадкой для откровенного обсуждения насущных проблем развития страны.

В 2000-х гг. Т.И. Заславская разработала целостную концепцию о современном трансформационном процессе в России и посткоммунистических обществах, его

\footnotetext{
${ }^{45}$ Татьяна Заславская - этапы яркой жизни в науке. URL: https://www.ieie.su/conf/socreads2017/tatyanazaslavskaya.html (дата обращения: 27.01.2019).

46 Заславская Т.И. О совершенствовании производственных отношений социализма и задачах экономической социологии (Новосибирский манифест) // Избранное: в 3 т. М., 2007. Т. 2. С. 11.

47 Заславская Т.И. «Я с детства знала, что самое интересное и достойное занятие - это наука» // Социологический журнал. 2007. № 3. URL: http://cdclv.unlv.edu/archives/Interviews/zaslavskaya_07.html (дата обращения: 11.02.2019).

48 Татьяна Ивановна Заславская. Некролог. URL: http:/www.isras.ru/index.php?page_id=1877 (дата обращения: 29.01.2019)
} 
механизмах, движущих силах, факторах, ограничениях, возможных и наиболее вероятных перспективах ${ }^{49}$.

В 2010-х гг. Татьяна Ивановна сосредоточилась на анализе экономически успешных экономических акторов и практик в российской институциональной среде, рассматривая их как модернизационный ресурс инновационного развития страны ${ }^{50}$.

Т.И. Заславская предложила междисциплинарный подход к изучению социального механизма развития экономики, который заложен в основу анализа проблем, возникающих на стыке экономической и социальной сфер общественной жизни, исследований социальноэкономического поведения разных общественных групп, социальных аспектов хозяйственного управления экономикой. Разработала ряд методологических и методических подходов к анализу сущности, векторов, тенденции и механизмов социальной трансформации современного общества на посткоммунистическом пространстве ${ }^{51}$.

Своим деятельным участием и авторитетом она поддерживала работу важных академических и общественных институций, являлась зам. председателя Объединенного ученого совета по экономическим наукам СО РАН (1985-1988 гг.), вице-президентом (1977-1986 гг.), президентом Советской социологической ассоциации (1986-1991), председателем Сибирского отделения ассоциации (с 1974 г.), ответственным редактором серии экономики и прикладной социологии журнала «Известия СО АН» (1984-1988), членом Совета РГНФ (с 1997), народным депутатом СССР (1989-1991), членом Межрегиональной депутатской группы, членом Высшего консультативно-координационного совета при Председателе Верховного Совета РФ (1990-1992 гг.), затем при Президенте РФ, почетным членом Польской академии наук (1987 г.), почетным доктором ряда зарубежных университетов.

Т.И. Заславская - лауреат Международной научной премии им. А.П. Карпинского (1990 г.), общенациональной неправительственной Демидовской премии (2000 г.), награждена орденами Октябрьской Революции (1987 г.), Трудового Красного Знамени (1975 г.), Дружбы народов (1981 г.), медалями ${ }^{52}$.

Умерла Татьяна Ивановна Заславская в Москве 23 августа 2013 г.

Идеи и методологические подходы Т.И. Заславской, увязывающие экономическую и социальную сферы общества, имеют вневременной эвристический потенциал, используются в современных исследованиях и обсуждаются на социально-экономических форумах.

Имя выдающегося ученого носит организованный Российской академией народного хозяйства и государственной службы при Президенте РФ в партнерстве с ИЭОПП СО РАН симпозиум «Социальные вызовы экономическому развитию», который стартовал в 2014 г. в Новосибирске, а затем проведен в Калининграде (2015 г.) и Ростове-на-Дону (2016 г.). Новосибирские научные чтения памяти Т.И. Заславской «Взаимодействие социальных и экономических процессов в обществе: вызов современности и перспективы исследования» на базе Института экономики и организации промышленного производства СО РАН и Новосибирского национального исследовательского университета вносят свой вклад в продвижение идей замечательного ученого ${ }^{53}$.

Жизнь Татьяны Ивановны вовсе не являлась величавым шествием к научной славе. Она упорно трудилась, разделила со своим поколением трудности и лишения. В профессиональной и общественной деятельности ученого четко просматривается уникальное соединение идеалов и ценностей, присущих дореволюционной русской интеллигенции и поколению «шестидесятников», ярким представителем которого Т.И. Заславская являлась ${ }^{54}$. На здании Института экономики и организации промышленного

\footnotetext{
49 Заславская Т.И. Современное российское общество: Социальный механизм трансформации: учебн. пособие. М., 2004. C. 9-13.

${ }^{50}$ Татьяна Заславская - этапы яркой жизни...

51 Заславская Татьяна Ивановна // Российская академия наук... Персональный состав. С. 98-99.

52 Там же.

${ }^{53}$ Татьяна Заславская - этапы яркой жизни...

${ }^{54}$ Татьяна Ивановна Заславская. Некролог...
} 
производства СО РАН установлена мемориальная доска «В этом здании в 1966-1988 гг. работала экономист и социолог академик Татьяна Ивановна Заславская». Труды замечательного ученого академика Т.И Заславской для многих поколений последователей сохраняют свою концептуальную силу и актуальность.

Женское измерение профессии ученого на основе вышеописанных методологических подходов и подробного изучения биографий академиков П.Я. Кочиной (Полубариновой) и Т.И. Заславской позволило сформировать представление (концепт) об «Академине» как о цельном образе женщины с ведущей интеллектуальной составляющей. В нем находит отражение совокупность профессиональных, личностных и ментальных качеств женщин, успешно работающих в академической системе на мировом и российском уровне, способствующих укреплению имиджа Российской Академии наук.

В области истории региональной науки обращение к новым аспектам, связанным с ролью женщин-ученых, поможет в полной мере раскрыть многогранный опыт деятельности Сибирского отделения РАН. Выделение в истории СО РАН личностного компонента актуализирует изучение трансляции гендерной, личностной и исторической идентичности в поле науки. Это будет способствовать продвижению женщин-ученых на новые уровни мирового и российского научного сообщества, усилению их влияния на позитивную динамику регионального социокультурного пространства Сибири в рамках перспективного проекта «Сибирские Академины», направленного на интеграцию науки, образования культуры, популяризацию научного наследия.

\section{Лumepamypa}

Век Лаврентьева. Новосибирск: Издательство СО РАН, филиал «Гео», 2000. 456 с.

Достопримечательное место «Новосибирский Академгородок»: научное и историкокультурное наследие. Новосибирск: ИПЦ НГУ, 2018. 162 с.

Евладов Б.В., Мокшин С.И. Золотая долина. Академгородок. (Репортаж из Новосибирского научного центра). М.: Политиздат, 1966. 127 с.

Заславская Т.И. Моя жизнь: воспоминания и размышления // Избранное: в 3 т. М.: Экономика, 2007. Т. 3. 764 с.

Заславская Т.И. О совершенствовании производственных отношений социализма и задачах экономической социологии (Новосибирский манифест) // Избранное: в 3 т. М.: Экономика, 2007. Т. 2. 636 с.

Заславская Т.И. Современное российское общество: Социальный механизм трансформации: учебн. пособие. М.: Дело, 2004. 400 с.

Заславская Т.И. Я с детства знала, что самое интересное и достойное занятие - это наука / Интервью // Социологические науки. 2007. № 3. С. 137-169.

Институт гидродинамики: люди, дела, даты... / отв. ред. А.А. Васильев. Новосибирск: Академическое изд-во «Гео», 2017. 674 с.

Историческая энциклопедия Сибири. Новосибирск: Издательский дом «Историческое наследие Сибири», 2009. Т. І. 715 с.

Пелагея Яковлевна Полубаринова-Кочина / отв. ред. В.В. Пухначев. Новосибирск: Академическое изд-во «Гео», 2013. 259 с.

Полубаринова-Кочина П.Я. Софья Васильевна Ковалевская, 1850-1891. М.: Наука, 1981. $321 \mathrm{c}$.

Российская академия наук. Сибирское отделение: Персональный состав / Е.Г. Водичев, Г.М. Запорожченко, О.Н. Калинина и др. Новосибирск: Наука, 2007. 603 с.

Российский академия наук. Сибирское отделение: Исторический очерк / Е.Г. Водичев, С.А. Красильников, В.А. Ламин и др. Новосибирск: Наука, 2007. 510 с.

Шола Томислав С. Мнемософия. Эссе о науке публичной памяти / ИКОМ России; ГМЗ «Ростовский Кремль». Ростов Великий, 2017. С. 171. 


\section{References}

Evladov, B.V., Mokshin, S.I. (1966). Zolotaya dolina. Akademgorodok. (Reportazh iz Novosibirskogo nauchnogo centra) [Golden Valley. Academgorodok. (Report from the Novosibirsk scientific center)]. Moscow.127 p.

Istoricheskaya entsiklopediya Sibiri [Historical encyclopedia of Siberia]. (2009). Novosibirsk. T. I. 715 p.

Pokrovskiy, N.N., Zaporozhchenko, G.M., Shelegina, O.N. (2018). Dostoprimechatelnoye mesto "Novosibirskiy Akademgorodok": nauchnoye i istoriko-kulturnoye naslediye ["Novosibirsk Akademgorodok" - place of interest: scientific, historical and cultural heritage]. Novosibirsk, Novosibirsk State University, Izdatelsko-poligraficheskiy tsentr NGU. 162 p.

Polubarinova-Kochina, P.Y. (1981). Sof'ya Vasil'evna Kovalevskaya, 1850-1891. [Sofya Kovalevskaya, 1850-1891]. Moscow. 321 p.

Puxnachev, V.V. (Ed.). (2013). Pelageya Yakovlevna Polubarinova-Kochina. Novosibirsk, GEO. 259 p.

Shola Tomislav, S. (2017). Mnemosofiya. Esse o nauke publichnoy pamyati [Mnemosophy. Essay on the science of public memory]. Rostov Velikiy. 171 p.

Vasil'ev, A.A. (Ed.). (2017). Institut gidrodinamiki: lyudi, dela, daty... [Institute of hydrodynamics: people, business, dates...]. Novosibirsk. 674 p.

Vek Lavrent'eva - Novosibirsk. (2000). [Century of Lavrentyev - Novosibirsk]. Novosibirsk. $456 \mathrm{p}$.

Vodichev, E.G., Krasil'nikov, S.A., Lamin, V.A. (2007). Rossiyskaya akademiya nauk. Sibirskoe otdelenie: Istoricheskiy ocherk [Russian Academy of Sciences. The Siberian Branch: a Historical sketch]. Novosibirsk. 510 p.

Vodichev, E.G., Zaporozhchenko, G.M., Kalinina, O.N. (2007). Rossiyskaya akademiya nauk. Sibirskoe otdelenie: Personal'niy sostav [Russian Academy of Sciences. Siberian branch: Personnel]. Novosibirsk. 603 p.

Zaslavskaya, T.I. (2004). Sovremennoe rossiyskoe obshchestvo: Sotsial'niy mekhanizm transformacii: tutorial [Modern Russian society: Social mechanism of transformation]. Moscow. $400 \mathrm{p}$.

Zaslavskaya, T.I. (2007). Moya zhizn': vospominaniya i razmyshleniya [My life: memories and reflections.]. In Izbrannoe: $v 3$ t. Moscow. V. 3.764 p.

Zaslavskaya, T.I. (2007). O sovershenstvovanii proizvodstvennykh otnosheniy sotsializma i zadachakh ehkonomicheskoy sotsiologii (Novosibirskiy manifest) [On improvement of production relations of socialism and tasks of economic sociology (Novosibirsk Manifesto)]. In Izbrannoe: $v 3 t$. Moscow. V. 2. $636 \mathrm{p}$.

Zaslavskaya, T.I. (2007). Ya s detstva znala, chto samoe interesnoe i dostoynoe zanyatie - eto nauka [I knew since childhood that the most interesting and worthy occupation is science]. Sotsiologicheskie nauki. No. 3, pp. 137-169.

Статья поступила в редакциию 25.04.2019 2. 